\title{
Application of Pattern Recognition Method for Color Assessment of Oriental Tobacco based on HPLC of Polyphenols*
}

\author{
by \\ S. Dagnon ${ }^{1}$ and A. Edreva ${ }^{2}$ \\ ${ }^{1}$ Institute of Tobacco and Tobacco Products, 4108 Plovdiv, Bulgaria \\ ${ }^{2}$ D. Kostoff Institute of Genetics, Bulgarian Academy of Sciences, 1113 Sofia, Bulgaria
}

\section{SUMMARY}

The color of Oriental tobaccos was organoleptically assayed, and high performance liquid chromatography (HPLC) of polyphenols was performed. The major tobacco polyphenols (chlorogenic acid, its isomers, and rutin), as well as scopoletin and kaempferol-3-rutinoside were quantified. HPLC polyphenol profiles were processed by pattern recognition method (PRM), and the values of indexes of similarity $\left(I_{\mathrm{s}}, \%\right)$ between the cultivars studied were determined. It was shown that data from organoleptic color assessment and from PRM based on HPLC profiles of polyphenols of the cultivars studied are largely compatible. Hence, PRM can be suggested as an additional tool for objective color evaluation and classification of Oriental tobacco. [Beitr. Tabakforsch. Int. 20 (2003) 355-359]

\section{ZUSAMMENFASSUNG}

Die Farbe von Orienttabaken wurde organoleptisch beurteilt und zusätzlich wurden die Polyphenole mittels Hochleistungsflüssigchromatographie (HPLC) bestimmt. Die wichtigsten Polyphenole im Tabak (Chlorogensäure, deren Isomere und Rutin), sowie auch Scopoletin und Kaempferol-3-rutinosid wurden quantifiziert. Die HPLCProfile der Polyphenole wurden mittels Muster-Erkennungsmethode (PRM) verglichen und Ähnlichkeitsindizes $\left(I_{\mathrm{s}}, \%\right)$ zwischen den untersuchten Zuchtsorten bestimmt. Es wurde gezeigt, dass die durch organoleptische Farbbestimmung und die durch PRM auf Basis der HPLCProfile der Polyphenole der untersuchten Zuchtsorten ermittelten Daten weitgehend kompatibel sind. Dies weist darauf hin, dass PRM als zusätzliches Instrument für objektive Farbevaluierung und Klassifikation von Orienttabaken genutzt werden kann. [Beitr. Tabakforsch. Int. 20 (2003) 355-359]

\section{RESUME}

La couleur des tabacs orientaux a été caractérisée par évaluation sensorielle. En même temps, les polyphénols ont été analysés par chromatographie liquide à haute performance (HPLC). La teneur des polyphénols majeurs du tabac (acide chlorogénique, ses isomères, rutine) ainsi que celle de la scopolétine et du kampférol-3-rutinoside a été determinée. Les profils chromatographiques des polyphénols ont été traités au moyen de la méthode de reconnaissance des patrons $(\mathrm{PRM})$, et les valeurs des index de similitude $\left(I_{\mathrm{s}}, \%\right)$ des variétés étudiées ont été calculées. Les données de PRM basées sur les profils chromatographiques des polyphénols sont totalement en accord avec les résultats obtenus par l'évaluation sensorielle de la couleur. Par conséquent, PRM peut être recommandée comme une méthode supplémentaire pour l'évaluation objective de la couleur et la classification des tabacs orientaux. [Beitr. Tabakforsch. Int. 20 (2003) 355-359]

\section{INTRODUCTION}

Polyphenols are a major group of secondary compounds in tobacco, their content amounting to more than $3 \%$. Their importance to tobacco quality has long been recognized (15). It is established that the polyphenols are directly related to tobacco leaf color, one of the basic indexes of tobacco quality that is formed during curing and fermentation $(6,7,8,14,19)$.

The current procedure for assessment of tobacco color is the organoleptical ranking $(3,12)$. Since this method is subjective, attempts have been made to develop more reliable techniques, such as reflectance spectrophotometry, but satisfactory results have been achieved only by statistical treatment of the data (12). In recent years, chemometrics, including pattern recognition methods (PRM), has been 
introduced for the objective estimation of a range of quality characteristics of natural products, such as aroma, taste, etc. and is applied to the quality assessment of essential oils, olive oils, fruits, and wines $(2,4,5,10,11,17)$. PRM relies on mathematical processing of chromatographic profiles of the constituents of natural products to provide discrete information in quantitative terms for purposes of quality estimation. Previously it was shown (1) that PRM based on high performance liquid chromatography (HPLC) profiling of polyphenols may be successfully used to objectively evaluate the color performance of Virginia tobacco. The aim of the present study is to test the applicability of the PRM-polyphenol HPLC approach as an additional tool for objective color estimation and classification of Oriental tobaccos. To this end, various Oriental cultivars grown in different locations of Bulgaria were studied. No data for application of PRM in evaluation of quality parameters of Oriental tobacco are available.

\section{EXPERIMENTAL}

\section{Material}

Oriental tobacco varieties Djebel 376, Djebel L1, Nevrokop 261, Krumovgrad 988, and Plovdiv 50 were used as experimental materials. They were released from a breeding program whose aim was the development of new Oriental tobacco varieties suitable for the soil and climatic conditions of the country and also met the requirements of the Tobacco Industry. The varieties Nevrokop 261 and Plovdiv 50 were obtained by intervarietal hybridisation of Oriental tobaccos $(16,18)$. The genitors of Nevrokop 261 are Nevrokop 5 (maternal parent) and the hybrid $\mathrm{F}_{1}$ (Dubek $566 \times$ Kulsko seme) (male parent) (16). The cultivar Plovdiv 50 results from a cross between $F_{11}$ (Harmanli $163 \times$ line 33) (female) and $\mathrm{F}_{10}[($ line $171 \times$ Krumovgradski) $\times($ Krumovgrad 988)] (male) (18). Krumovgrad 988 is a selection of a local population (13). Djebel 376 and Djebel L1 are experimental lines from type "basma" (D. Dimanov, personal communication). All varieties studied are fertile. Plants were grown under agrotechnical conditions appropriate for Oriental tobaccos. Experiments were carried out in 4 replicates. The spacing between rows was $35-45 \mathrm{~cm}$, and between plants was $8-10 \mathrm{~cm}$. They were cultivated in different locations of the tobacco-producing region of South Bulgaria: Svilengrad, Kardjali, Asenovgrad, Plovdiv, Gotze Delchev, Dupnitza, and Bansko. Only leaves classified as first class were analyzed.

\section{Sensory color evaluation}

Color was assayed according to a scale encompassing five basic and intermediary colors: yellow, red, orange, yelloworange, and orange-red (3). Basic colors are expressed as follows: yellow, 10; red, 20; orange, 15. Intermediary colors are expressed as arithmetic means of the basic colors, namely: orange to orange-red $[15+(15+20) / 2] / 2$ $=16.2$; yellow-orange $(10+15) / 2=12.5$. Green shades were not included in the arithmetic calculation. The color evaluation was performed by panels of five experts. Values are significantly different at $P \leq 5 \%$ (Student's $t$ test).

\section{HPLC of polyphenols}

The leaf material was extracted with aqueous methanol $\left[\mathrm{CH}_{3} \mathrm{OH}: \mathrm{H}_{2} \mathrm{O}=60: 40(\mathrm{v} / \mathrm{v})\right]$. Fractionation of the extract was done with cartridge $\mathrm{C} 18$ according to COURT et al. (9). Polyphenols were determined by use of the reversed phase HPLC method $(20,21)$. Chromatography was carried out under the following conditions to allow maximum separation of chlorogenic acid from its isomer 4-0-caffeoylquinic acid: liquid chromatograph Perkin Elmer (Perkin Elmer Ltd. Beaconsfield, Buckinghamshire, England) equipped with an LC290 binary pump, LC290 UV/VIS detector, and LCI-100 integrator; analytical column Kromasil LC18, 150 mm, 5 m, 4.6 mm i.d. (Supelco Park, Bellefonte, PA, USA); single wavelength at $340 \mathrm{~nm}$, eluent flow rate $1.0 \mathrm{mLmin}^{-1}$; sample volume $20 \mu \mathrm{L}$; solvent composition $\mathrm{A}=$ $\mathrm{CH}_{3} \mathrm{OH}: \mathrm{H}_{2} \mathrm{O}: \mathrm{CH}_{3} \mathrm{COOH}=5: 93: 2 ; \quad \mathrm{B}=\mathrm{CH}_{3} \mathrm{OH}$ : $\mathrm{H}_{2} \mathrm{O}: \mathrm{CH}_{3} \mathrm{COOH}=86: 12: 2$. Gradient elution profile was $100 \% \mathrm{~A} ; 0 \mathrm{~min} ; 20 \mathrm{~min}$ to $85 \% \mathrm{~A} ; 5 \mathrm{~min}$ to $80 \% \mathrm{~A} ; 17$ $\min$ to $45 \% \mathrm{~A} ; 5$ min to $100 \% \mathrm{~A}$ or 5 min to $0 \% \mathrm{~A}$ for cleaning.

The reproducibility of the method is good with typical standard deviation of about $2 \%$ for chlorogenic acid, scopoletin, and rutin. Peaks of chlorogenic acid, scopoletin, and rutin were identified by comparison with reference compounds. Peak assignments for those components where no references were available (neochlorogenic acid, 4- 0 caffeoylquinic acid, and kaempferol-3-rutinoside) were based on retention time data reported by SNOOK and CHORTYK (20). The contents of chlorogenic acid, rutin, and scopoletin were calculated from the peak area of the corresponding reference. Neochlorogenic and 4-0-caffeoylquinic acids were quantified with chlorogenic acid as a standard and kaempferol-3-rutinoside with rutin as a standard. Five replicate analyses were performed. The average was used to calculate both polyphenol content and PRM. Significance of differences was derived from the Student's $t$ test at $P \leq 5 \%$.

\section{PRM}

PRM was performed according to the Package software program "Patreco" (10) (Pharmaceutical Institute, Sofia, Bulgaria). Processing of HPLC profiles involved all 12 peaks present for each sample. The matrix for PRM was designed from the retention time of the peaks and the percent ratio of the height of each peak to the sum of the heights of all selected peaks. PRM data are presented as indexes of similarity $\left(I_{\mathrm{s}}, \%\right)(10) . I_{\mathrm{s}}$ of $98 \%$ is considered as a limit value. Above this value, differences are not significant.

\section{RESULTS AND DISCUSSION}

In general, the analysis of polyphenols is confined to the determination of the so-called "typical five" in tobacco: chlorogenic acid (3-0-caffeoylquinic) and its isomers neochlorogenic acid (5-0-caffeoylquinic) and 4-0-caffeoylquinic acid, scopoletin, and the flavonoid rutin. Compounds such as caffeic acid, scopoletin, kaempferol-3-rutinoside, and others $(6,15,21)$ are present in very low amounts and 
Table 1. Content of polyphenols (\% dry matter), and organoleptic assessment of color of Oriental tobacco varieties grown in different locations of South Bulgaria. Data are means from five replicates. Standard deviations are less than $10 \%$ of the means. Values are significantly different at $P \leq 5 \%$ (Student's $t$-test).

\begin{tabular}{|c|c|c|c|c|c|c|c|c|c|c|}
\hline $\begin{array}{l}\text { Sample } \\
\text { no. }\end{array}$ & Cultivar location & $\begin{array}{c}\text { Chloro- } \\
\text { genic acid }\end{array}$ & $\begin{array}{l}\text { Neochloro- } \\
\text { genic acid }\end{array}$ & $\begin{array}{c}\text { 4-0-caffeoyl- } \\
\text { quinic acid }\end{array}$ & Scopoletin & Rutin & $\begin{array}{l}\text { Kaempferol- } \\
\text { 3-rutinoside }\end{array}$ & Total & Color & $\begin{array}{l}\text { Color } \\
\text { score }\end{array}$ \\
\hline 1 & $\begin{array}{l}\text { Djebel } 376 \\
\text { (Parvenetz, } \\
\text { Plovdiv) }\end{array}$ & 0.35 & 0.09 & 0.05 & 0.001 & 0.49 & 0.12 & 1.10 & Red & 20.0 \\
\hline 2 & $\begin{array}{l}\text { Djebel L1 } \\
\text { (Trepetlika, } \\
\text { Kardjali) }\end{array}$ & 1.43 & 0.32 & 0.40 & 0.001 & 0.81 & 0.30 & 3.26 & Yellow-orange & 12.5 \\
\hline 3 & $\begin{array}{l}\text { Nevrocop } 261 \\
\text { (Valcosel, } \\
\text { G. Delchev) }\end{array}$ & 1.26 & 0.30 & 0.25 & 0.003 & 0.98 & 0.20 & 2.99 & Orange & 15.0 \\
\hline 4 & $\begin{array}{l}\text { Nevrocop } 261 \\
\text { (Gaytaninovo, } \\
\text { G. Delchev) }\end{array}$ & 1.04 & 0.20 & 0.23 & 0.003 & 0.75 & 0.25 & 2.47 & $\begin{array}{l}\text { Orange with } \\
\text { green shades }\end{array}$ & 15.0 \\
\hline 5 & $\begin{array}{l}\text { Krumovgrad } 988 \\
\text { (Mladinovo, } \\
\text { Svilengrad) }\end{array}$ & 0.96 & 0.09 & 0.16 & 0.003 & 0.78 & 0.19 & 2.18 & Orange-red & 17.5 \\
\hline 6 & $\begin{array}{l}\text { Plovdiv } 50 \\
\text { (Topolovo, } \\
\text { Asenovgrad) }\end{array}$ & 1.23 & 0.09 & 0.22 & 0.002 & 0.60 & 0.38 & 2.52 & Yellow & 10.0 \\
\hline
\end{tabular}

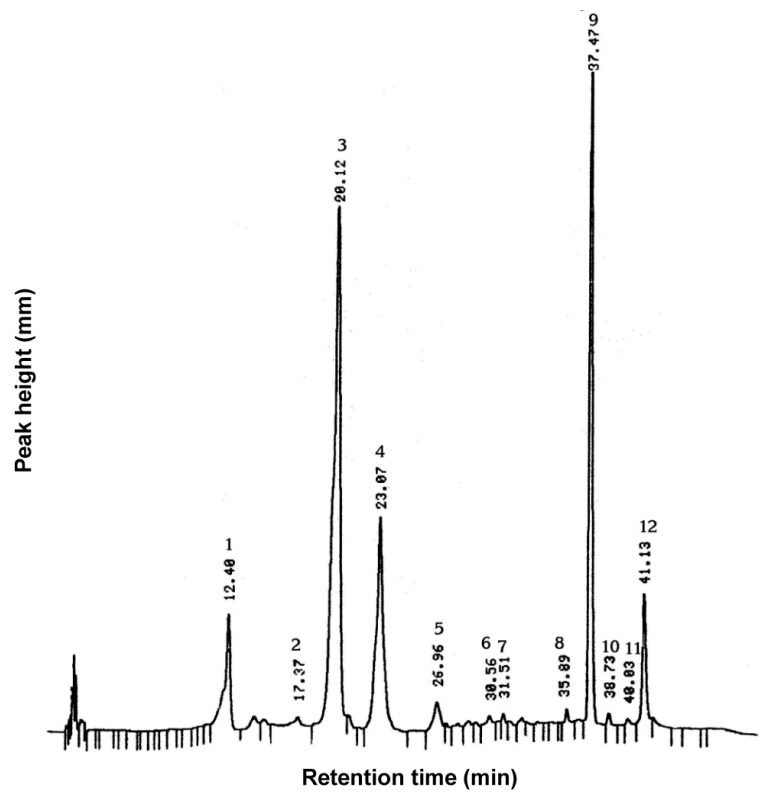

Figure 1. HPLC separation of polyphenols in Oriental tobacco variety Djebel L1, location Trepetlika, Kardjali; Component 1 = neochlorogenic acid (5-0-caffeoylquinic), Component $3=$ chlorogenic acid (3-0-caffeoylquinic), Component $4=4-0-$ caffeoylquinic acid, Component $7=$ scopoletin, Component $9=$ rutin, Component 12 = kaempferol-3-rutinoside.

thus have no impact on tobacco quality. In the HPLC polyphenol pattern of all samples studied, a total of 12 welldefined peaks were observed (Figure 1). The major peaks are Peaks 1, 3, 4, 9, and 12. Peak 1 was identified as neochlorogenic acid $\left(t_{R}=12.40\right)$, peak 3 as chlorogenic acid $\left(t_{R}\right.$ $=20.12)$, peak 4 as 4-0-caffeoylquinic acid $\left(t_{R}=23.07\right)$, peak 7 as scopoletin $\left(t_{R}=31.51\right)$, peak 9 as rutin $\left(t_{R}=\right.$ $37.47)$, and peak 12 as kaempferol-3-rutinoside $\left(t_{R}=\right.$ 41.13). The remaining components (the minor peaks 2,5 , $6,8,10$, and 11) were not identified.
Table 2. Similarity indexes $\left(I_{s}, \%\right)$ of Oriental tobacco varieties

\begin{tabular}{l|c|c|c|c|c|c}
\hline Sample no. & 1 & 2 & 3 & 4 & 5 & 6 \\
\hline 1 & $\mathrm{X}$ & 73.4 & 78.4 & 78.5 & 78.7 & 66.7 \\
2 & - & $\mathrm{X}$ & 92.6 & 92.7 & 92.1 & 90.3 \\
3 & - & - & $\mathrm{X}$ & 98.3 & 96.9 & 84.7 \\
4 & - & - & - & $\mathrm{X}$ & 96.8 & 85.1 \\
5 & - & - & - & - & $\mathrm{X}$ & 85.9 \\
6 & - & - & - & - & - & $\mathrm{X}$ \\
\hline
\end{tabular}

Note: Nos. 1, 2, 3, 4, 5, and 6 are the samples listed in Table 1.

The content of polyphenols, the color, and color scores of different Oriental tobacco cultivars are summarized in Table 1 . Their similarity indexes $\left(I_{\mathrm{s}}, \%\right)$ are shown in Table 2. It is obvious that Djebel $376 \mathrm{cv}$. (Sample 1) differs from the rest in its color, color score, and total polyphenol content (Table 1). The same differentiated color performance of this genotype compared to the other cultivars is also evident from the data of $I_{\mathrm{s}}$ that show low values, less than 79\% (Table 2). The divergent position of Djebel 376 $\mathrm{cv}$. is most clearly expressed with respect to Plovdiv $50 \mathrm{cv}$. (Sample 6). These two genotypes exhibit contrasting colors (red and yellow, respectively), color scores (20.0 and 10.0, respectively), as well as total polyphenol content $(1.10 \%$ and $2.52 \%$, respectively) (Table 1). This is in accord with the low $I_{\mathrm{s}}$ between them $(66.7 \%)$ (Table 2$)$. The above data reflect the genotypic specificity of both Oriental tobaccos (Djebel 376 and Plovdiv 50) originating from different parental crosses. The group of the other Oriental tobaccos (Samples 2, 3, 4, and 5) show similar polyphenol content and color scores (Table 1) corresponding to a higher index 
Table 3. Content of polyphenols (\% dry matter), and organoleptic assessment of color of Oriental tobacco variety Djebel L1 from different locations. Data are means from five replicates. Standard deviations are less than $10 \%$ of the means. Values are significantly different at $P \leq 5 \%$ (Student's $t$-test).

\begin{tabular}{|c|c|c|c|c|c|c|c|c|c|c|}
\hline $\begin{array}{l}\text { Sample } \\
\text { no. }\end{array}$ & Cultivar location & $\begin{array}{c}\text { Chloro- } \\
\text { genic acid }\end{array}$ & $\begin{array}{l}\text { Neochloro- } \\
\text { genic acid }\end{array}$ & $\begin{array}{l}\text { 4-0-caffeoyl- } \\
\text { quinic acid }\end{array}$ & Scopoletin & Rutin & $\begin{array}{l}\text { Kaempferol- } \\
\text { 3-rutinoside }\end{array}$ & Total & Color & $\begin{array}{l}\text { Color } \\
\text { score }\end{array}$ \\
\hline 1 & $\begin{array}{l}\text { Krumovo, } \\
\text { Dupnitza }\end{array}$ & 0.68 & 0.12 & 0.20 & 0.003 & 0.62 & 0.21 & 1.83 & Orange-red & 17.5 \\
\hline 2 & $\begin{array}{l}\text { Sladun, } \\
\text { Svilengrad }\end{array}$ & 0.80 & 0.27 & 0.30 & 0.001 & 0.70 & 0.17 & 2.21 & $\begin{array}{l}\text { Orange to } \\
\text { orange-red }\end{array}$ & 16.2 \\
\hline 3 & $\begin{array}{l}\text { Valcosel, } \\
\text { G. Delchev }\end{array}$ & 1.18 & 0.32 & 0.35 & 0.003 & 0.85 & 0.35 & 3.05 & $\begin{array}{l}\text { Orange with } \\
\text { green shades }\end{array}$ & 15.0 \\
\hline 4 & $\begin{array}{l}\text { Trepetlika, } \\
\text { Kardjali }\end{array}$ & 1.43 & 0.32 & 0.40 & 0.001 & 0.81 & 0.30 & 3.26 & Yellow-orange & 12.5 \\
\hline 5 & Bansko & 0.78 & 0.13 & 0.29 & 0.002 & 0.56 & 0.23 & 1.99 & $\begin{array}{l}\text { Orange to } \\
\text { orange-red }\end{array}$ & 16.2 \\
\hline
\end{tabular}

Table 4. Similarity indexes $\left(I_{s}, \%\right)$ of Oriental tobacco variety Djebel L1 from different locations

\begin{tabular}{l|cccccc}
\hline Sample no. & 1 & 2 & 3 & 4 & 5 \\
\hline 1 & $\mathrm{X}$ & 92.2 & 90.6 & 89.0 & 87.1 \\
2 & - & $\mathrm{X}$ & 94.0 & 93.1 & 89.7 \\
3 & - & - & $\mathrm{X}$ & 95.0 & 92.3 \\
4 & - & - & - & $X$ & 93.6 \\
5 & - & - & - & - & $X$ \\
\hline
\end{tabular}

Note: Nos. 1, 2, 3, 4, and 5 are samples of Djebel L1 variety from different locations (see Table 3 ).

of similarity (Table 2). Almost indistinguishable are Samples 3 and 4 with equal color scores and similar polyphenol content, values compatible with a very high $I_{\mathrm{s}}$ (98.3\%) (Tables 1 and 2). These data seem quite logical if it is assumed that both samples belong to the same genotype, Nevrokop 261, and differ only in their cultivation location. Thus, it may be possible that environmental conditions are less important for color performance than the genotypic characteristics.

The data of Djebel L1, grown in five different localities, support this conclusion. A not important variation of color shades and color scores among the different specimens was established (Table 3). Proximity in color performance is in agreement with the high values of $I_{\mathrm{s}}$, varying between narrow limits (Table 4). This relationship is particularly evident in Samples 3 and 4 where their similar polyphenol content (3.05\% and 3.26\%), color, and color scores (15.0 and 12.5$)$ are fully compatible with a high $I_{\mathrm{s}}$ value, $95.0 \%$ (Tables 3 and 4).

The results herein presented show that PRM provides a numerical expression $\left(I_{\mathrm{s}}, \%\right)$ that is in accord with the organoleptic estimation of color. The method provides a possibility for Oriental tobacco classification and may contribute to objective leaf quality assessment.

\section{CONCLUSION}

PRM data, based on HPLC profiling of polyphenols, are in agreement with those from sensory evaluation of color. Thus, PRM provides a means for objective tobacco classification, especially useful for tobaccos of wide color diversity such as Oriental tobacco. PRM can be used in breeding programs aimed at the optimization of polyphenol content.

\section{REFERENCES}

1. Apostolova, E., S. Dagnon, and A. Edreva: Characterization of Virginia tobaccos by chemometric methods; Beitr. Tabakforsch. Int. 20 (2002) 1-6.

2. Benavides A., I. Recasens, T. Casero, and J. Puy: Chemometric analyses of "Golden Smoothee" apples treated with two preharvest calcium spray strategies in the growing season; J. Sci. Food Agr. 8 (2001) 943-952.

3. Bulgarian state standard 9271-85: Processed and fermented Bulgarian Oriental tobacco; General Agency of Standardisation, Sofia, 1985.

4. Cantagrel, R.: Application de l'analyse statistique multidimensionnelle à la différenciation des huiles essentielles de lavandes et de lavandins [Application of statistical multidimensional analysis to the differentiation of essential oils of lavenders (lavandes and lavandins)]; Parfums, Cosmétiques, Arômes 61 (1985) 73-76.

5. Carratala, M., C. Garcia-Lopez, V. Berenguer-Navarro, and N. Grane-Teruel: New contribution to the chemometric characterization of almond cultivars on the basis of their fatty acid profiles; J. Agr. Food Chem. 46 (1998) 963-967.

6. Court, W.A.: High-performance reversed-phase liquid chromatography of naturally occurring phenolic compounds; J. Chromatogr. 130 (1977) 287-291.

7. Court, W.A., M.R. Binns, and J.G. Hendel: Examination of the influence of curing and stalk position on the phenolic constituents of flue-cured tobacco; Tob. Sci. 27 (1983) 51-55. 
8. Court, W.A. and J.G. Hendel: Phenolic constituents of flue-cured tobacco at different stages of plant growth; Tob. Sci. 29 (1985) 73-76.

9. Court, W.A., J.G. Hendel, and R. Poce: Fractionation of flue-cured tobacco samples using Sep-Pak cartridges; Tob. Sci. 35 (1991) 59-62.

10. Dimov, N., A. Tsoutsoulova, and R. Stojanov: Pattern recognition methods for discrimination of essential oils (rose oils) by their gas chromatograms; Perfumer \& Flavorist 12 (1987) 45-48.

11. Forina, M. and E. Tiscorina: Pattern recognition methods in the prediction of Italian olive oils by their fatty acid content; Annali di Chimica 72 (1982) 143-146.

12. Garcia, M., D. Barreiro, and M. Ruiz-Altisent: Development of a virtual expert for color classification of tobacco leaves. Validation against human experts; in: Sensoral 98 - International Workshop on Sensing Quality of Agricultural Products, Cemagref Editions, Montpellier, France; Actes de Colloque, TechnologyAgronomy Section 1, 2000, p. 3086.

13. Georgiev, Ch.: Karchene i filizene na sortovete Harmanli 163 i Krumovgrad 988 [Topping and suckering of varieties Harmanli 163 and Krumovgrad 988]; Bulg. Tobacco 6 (1977) 30.

14. Grabuloski, T. and Z. Taseska: Study of the correlation between the color of tobacco and the polyphenol content of Prilep tobacco; Tutun (Tobacco) 3-4 (1977) 227-291.

15. Kallianos, A.G.: Phenolics and acids in leaf and their relationship to smoking quality and aroma; Rec. Adv. Tob. Sci. 2 (1976) 61-79.
16. Lulov, K.: Niakoi biologichni osobenosti i agrotechnicheski iziskvania na sort Nevrokop 261 [Some biological characteristics and agrotechnical reguirement for variety Nevrocop 261]; Bulg. Tobacco 4 (1972) 21-24.

17. Noble, A.C.: Sensory and instrumental evaluation of wine aroma; in: Analysis of foods and beverages, Academic Press Inc., N.Y., 1978, pp. 203-228.

18. Popchristev, V.: Sort Plovdiv 50 [Variety Plovdiv50]; Bulg. Tobacco 1 (1988) 15-18.

19. Smeeton, B. and M. Edwards: The influence of genotype and curing on the polyphenol content of flue-cured tobacco polyphenols; Inf. Bull. CORESTA 3 (1993) 80.

20. Snook, M.E. and O.T. Chortyk: An improved extraction-HPLC method for tobacco polyphenols; Tob. Sci. 26 (1982) 25-29.

21. Stotesbury, S.J.: A method for the determination of polyphenols in tobacco by HPLC, its application to the analysis of various tobacco types, and to the analysis of smoke; Inf. Bull. CORESTA 3 (1993) 21.

Address for correspondence:

Aglika Edreva
Bulgarian Academy of Sciences,
Institute of Genetics,
1113 Sofia,
Bulgaria

